\title{
Weigela floribunda ve Spiraea $x$ vanhouttei'nin çelik ile üretilmesinde farklı sera ortamları ve büyüme hormonlarının köklenme üzerine etkileri
}

\author{
Effects of different greenhouse media and hormones on Propagation by Cutting of Weigela floribunda and Spiraea $x$ \\ vanhouttei
}

\author{
Zafer YÜCESAN, Ali Ömer ÜÇLER, Ercan OKTAN, Ali BAYRAKTAR, Tuncel ŞAFAK
}

Karadeniz Teknik Üniversitesi, Orman Fakültesi, Orman Mühendisliği Bölümü, Trabzon, Türkiye

\section{Eser Bilgisi / Article Info}

Araştırma makalesi / Research article

DOI: 10.17474 /artvinofd.330622

Sorumlu yazar / Corresponding author Zafer YÜCESAN

e-mail: yucesan@ktu.edu.tr

ORCID: 0000-0003-2261-9333

Geliş tarihi / Received

24.07.2017

Düzeltme tarihi / Received in revised form

30.11.2017

Elektronik erişim / Online available

08.12.2017

Anahtar kelimeler:

Gelin tacl

Beyaz çiçekli ispirye

Vejetatif üretim

Sera ortamı

Oksin

\section{Keywords:}

Crimson weigela

Vanhoutte spirea

Vegetative propagation

Greenhouse media

Auxin

\begin{abstract}
Özet
Bu çalışmada, peyzaj çalışmalarında yaygın olarak kullanılan Weigela floribunda (Sieb. and Zucc.) K. Koch türü ve Spiraea $x$ vanhouttei (Briot) Zabel hibrit türünün çelikle üretilmesinde farklı sera ortamları (Sera-1 ortamı; hava sıcaklığı $20 \pm 2^{\circ} \mathrm{C}$, köklendirme ortamı alt sıcaklığı $20 \pm 2^{\circ} \mathrm{C}$ ve nem $\% 70 \pm 2$, Sera-2 ortamı; hava sıcaklığı $20 \pm 2^{\circ} \mathrm{C}$, köklendirme ortamı alt sıcaklığı $25 \pm 2^{\circ} \mathrm{C}$ ve nem $\% 70 \pm 2$ ) ve büyüme hormonlarııı (IBA ve NAA) farklı dozlarının (1000 ve 5000 ppm) köklenme başarısı üzerine etkileri araştırıımıştır. Çalışma kapsamında, ilk kallus oluşumu, ilk kök oluşumu, kök boyu (KB), kök sayısı (KS) ve köklenme yüzdeleri (KY) belirlenmiştir. Her iki tür için de en yüksek köklenme başarısı \%100 olarak tespit edilmiştir. Weigela floribunda türü için bu değer, Sera-1 ortamında Kontrol, IBA 5000 ppm, NAA 1000 ppm ve NAA 5000 ppm işlemlerinde, Sera-2 ortamında ise NAA 1000 ppm ve 5000 ppm işlemlerinde tespit edilmiştir. Spiraea $x$ vanhouttei hibrit türü için ise, Sera-1 ortamındaki Kontrol ve IBA 5000 ppm işlemlerinde meydana gelmiştir. KB ve KS açısından, Sera-1 ortamında Weigela floribunda için, Sera-2 ortamında Spiraea $x$ vanhouttei için çalışmadaki en yüksek sonuçlar elde edilmiştir. Ayrıca ölçülen diğer özellikler üzerinde sera ortamları ve hormonların etkisi istatistiksel açıdan değerlendirilmiştir.
\end{abstract}

\begin{abstract}
In the present study, the effects on rooting success of different greenhouse media (Greenhouse-1 media with air temperature at $20 \pm 2^{\circ} \mathrm{C}$, rooting table temperature at $20 \pm 2^{\circ} \mathrm{C}$ and humidity at $70 \% \pm 2$, Greenhouse- 2 media with air temperature at $20 \pm 2^{\circ} \mathrm{C}$, rooting table temperature at $25 \pm 2^{\circ} \mathrm{C}$ and humidity at $70 \% \pm 2$ ) and different doses (1000 and $5000 \mathrm{ppm}$ ) of hormones (IBA and NAA) on propagation by cutting of Weigela floribunda (Sieb. and Zucc.) K. Koch and Spiraea $x$ vanhouttei (Briot) Zabel which are widely used in landscape studies were investigated. First callus and root formation, root length (RL), the number of root (RN) and rooting percentage (RP) were determined in the scope of this study. For both species, the highest rooting success was determined as $100 \%$. For Weigela floribunda, the highest rooting percentage was determined in Control, IBA 5000 ppm, NAA 1000 ppm and NAA 5000 ppm treatments in Greenhouse-1 media, and also in NAA 1000 ppm and NAA 5000 ppm treatments in Greenhouse-2 media. For Spiraea $x$ vanhouttei, the highest rooting percentage was determined in Control and IBA 5000 ppm treatments in Greenhouse-1 media. In terms of root length and the number of roots, the highest results were obtained in Greenhouse-1 media for Weigela floribunda, in Greenhouse-2 media for Spiraea $x$ vanhouttei. Also, the effects of greenhouse media and hormones on other measured characteristics were statistically evaluated.
\end{abstract}

\section{GiRiş}

Yüzyıllardır estetik amaçlarla kullanılan süs bitkileri hızla artan kentleşmeye bağlı olarak, insanların doğa özleminin giderilmesi, kentlerin daha yaşanılır ortamlar haline dönüştürülmesi ve buna benzer amaçlarla günümüzde çok daha fazla kullanılmaktadır. Ayrıca süs bitkileri sektörü, bugün birçok ülkenin ekonomik olarak kalkınmasında çok önemli rol oynayan ticari bir alan olarak dikkat çekmektedir. Dolayısıyla, geniş bitkisel biyoçeşitliliğe sahip olan Türkiye'nin bu sektörde kendine daha fazla yer bulması için, süs bitkilerinin üretiminin artırılması önem arz etmektedir. Kesme çiçek, iç mekân süs bitkileri, dış mekan süs bitkileri ve doğal çiçek soğanları olmak üzere dört farklı alanda üretimi yapılmakta olan süs bitkileri yetiştiriciliğinde yaşanan hızlı gelişmeye paralel olarak, ekonomik açıdan süs bitkilerinin önemi de artmaktadır (Şirin 2003). Dolayısıyla, süs bitkisi üretim ve tüketiminde önemli değişiklikler yaşanmakta ve sektör içerisinde önemli bir rekabet ortamı oluşmaktadır. 
Ay (2009), Dünya'da yaklaşık 145 ülkede 220.000 hektar alanda süs bitkisi üretimi yapıldığını ve ticaret hacminin ise 50 milyar dolar civarında olduğunu belirtmektedir. Kızıloğlu vd. (2012), Türkiye'nin, süs bitkileri yetiştiriciliğinde uygun iklimsel ve coğrafi koşulları, pazar ülkelere yakınlığı ve ucuz işgücüne sahip olması gibi nedenlerle önemli avantajlara sahip olduğunu ifade etmektedir. Süs bitkisi yetiştiriciliğinde önemli bir konumda bulunan Türkiye'nin, doğru planlama ve üretim teknikleri ile süs bitkisi yetiştiriciliğinde pazar payını artırma olasılığı çok yüksektir.

Vejetatif üretme yöntemi süs bitkileri üretiminde temeldir. Vejetatif üretme yöntemi içerisinde çelikle üretme yöntemi üretilecek bitkiden alınan ve çelik olarak adlandırılan bir gövde, kök veya yaprak parçası ile yeni bir bitki oluşturma tekniğidir. (Ermeydan vd. 2011). Çelikle üretme yönteminin en genel şekli gövde çelikleriyle üretmedir (Boydak ve Çalışkan 2014). Odunlaşma durumu ve alındıkları döneme göre gövde çelikleri; yumuşak (yeşil), yarı odunlaşmış (odunsu) ve odun (sert) çelikler olarak sınıflandırılır (Ürgenç 1992). Odunsu bitkilerin henüz odunlaşmamış olan taze ilkbahar sürgünlerinden hazırlanan çeliklere yumuşak çelik adı verilmekte ve birçok süs bitkisi bu çeliklerle üretilebilmektedir. Yumuşak çelikler daha çabuk ve kolay köklenirler. Yumuşak çelikle üretme yönteminde çelik alma zamanının türlere ve iklim koşullarına göre isabetli seçilmesi çeliklerin köklenmesinde çok etkilidir (Megep 2007; Demirbaş 2010; Ermeydan vd. 2011).

Bitkilerin çelikle üretilmelerinde köklenmeyi etkileyen birçok faktör vardır. Bu faktörler; kimyasal faktörler (hormonlar, karbonhidratlar vb.), bitki faktörleri (çelik alma zamanları, çelik tipi, tür ve çeşitlerin etkileri vb.), çevresel faktörler (nem kontrolü, ışık ilavesi, alttan ısıtma, fotoperiyot $v b$.) ve diğer faktörler (ortam, yaralama vb.) olarak belirtilebilir (Demirbaş 2010). Uygun köklendirme ortamının tespit edilmesi çeliklerin köklenmesi için önem arz etmektedir. Ayrıca, başarılı bir köklenmenin sağlanması için gereken önemli bir dış etken de nemdir. Hazırlanan çeliklerin düşük nem durumundan ötürü kurumamalarının sağlanması ya da yüksek nemden hastalanmamaları adına optimal ortam nemi koşullarını sağlamak hayati önem taşımaktadır (Jaenicke ve Beniest 2002).

Hormonlar da çelik ile üretme sürecinde çok yüksek öneme sahiptir. Hücrelerin bölünmesine, genişlemesine ve büyümesine neden olan oksinler (IBA, IAA, NAA) bitkilerde büyüme ve gelişmeyi etkileyen en önemli grup olup, kök oluşumuna katkı sağlamaktadır (Çetin 2002; Grunewald vd. 2009). Oksin grubu hormonlar içerisinde yer alan, Indol bütrik asit (IBA) çeliklerin köklendirilmesinde en yaygın olarak kullanılan sentetik hormondur (Kaynak ve Ersoy 1997). IAA ile karşılaştırıldığında çelikleri köklenmeye teşvik etmesi daha da yüksektir (Epstein ve Ludwig-Müller 1993). IBA yıkan enzim sistemleri tarafından yavaş parçalanmaktadır ve çok yoğun (1000 - 8000 ppm) ve seyreltik (10-250 ppm) solüsyon şeklinde uygulanmaktadır (Weaver 1972). Özellikle zor köklenen türlerde çeliklerin kök oluşumunu hızlandırmak üzere kök sayısını ve kalitesini artırmaktadır (Zenginbal vd. 2006). Naftalin asetik asit (NAA) ve türevleri ise, çelik köklendirilmesinde ve çiçeklenmenin teşvik edilmesinde etkilidir (Kaynak ve Ersoy, 1997).

Çalışma kapsamında Weigela floribunda ve Spiraea $x$ vanhouttei türlerinin çelikle üretiminde farklı sera ortamlarının ve hormonların köklenme başarısı üzerine etkisi araştırılmış olup türlerin ilk kallus ve kök oluşumu, kök boyu (KB), kök sayısı (KS) ve köklenme yüzdeleri (KY) belirlenmiştir.

\section{MATERYAL ve YÖNTEM}

\section{Materyal}

Çalışma, Karadeniz Teknik Üniversitesi bünyesinde yer alan Orman Fakültesi Araştırma ve Uygulama Serası'nda 2016 yılında gerçekleştirilmiştir. Teknolojik sera koşullarına sahip olan bu serada, otomasyon sistemi ile ayarlanabilen Isıtma sistemi, sisleme ve mistleme, ISI perdesi ve gölgeleme, havalandırma pencereleri, soğutma amaçlı fan-pad, çatı havalandırma, ısıtma sistemli köklendirme masaları bulunmaktadır. Araştırma, iki bölümü içeren cam serada yapılmıştır. Sera-1 ortamında $20 \pm 2^{\circ} \mathrm{C}$ hava sıcaklığı, $20 \pm 2^{\circ} \mathrm{C}$ köklendirme masası alt sıcaklığı ve nem $\% 70 \pm 2$ olarak ayarlanmıştır. Sera-2 ortamında ise hava sıcaklığı $20 \pm 2^{\circ} \mathrm{C}$, köklendirme masası alt sıcaklığı $25 \pm 2^{\circ} \mathrm{C}$ ve nem $\% 70 \pm 2$ olacak şekilde 
sera otomasyonunun bilgisayar ortamında düzenlenmiştir. Köklendirme ortamı olarak yüksek su tutma kapasitesi ve havalanma porozitesine sahip olması nedeniyle her iki sera ortamında da perlit kullanılmıştır. Weigela floribunda türü ve Spiraea $x$ vanhouttei hibrit türünün Haziran ayında alınan yumuşak çelikleri kullanılmışır. Çelik materyalleri KTÜ yerleşkesindeki anaçlardan seçilmiştir.

\section{Yöntem}

Yumuşak çeliklerin dikimi, "tesadüfi bloklar deneme desenine" göre üç tekerrürlü ve her tekerrürde 10 çelik olacak şekilde yapılımıştır. Çalışmada, 2 tür $\times 2$ hormon $\times 2$ doz $\times 2$ sera ortamı $\times 10$ çelik $\times 3$ tekrar ve 120 kontrol çeliği olmak üzere toplam 600 adet çelik köklendirmeye alınmıştır. Sabah erken saatlerde anaç bireylerden alınan bitki materyali ile 10-12 cm uzunluğunda çelikler hazırlanmıştır. Köklenme sürecinde yapraklardan oluşacak su kaybını azaltmak için çeliklerin alt kısmındaki yapraklar koparılmış, üst kısımda ise yaprakların yarısı kesilerek 2-3 adet yarım yaprak bırakılmıştır.

Köklendirme işlemi için köklenmeye teşvik edici oksin grubu hormonlardan Indol Bütrik Asit (IBA) ve Naftalin Asetik Asit (NAA) hormonlarının toz formülasyonları 1000 ppm ve 5000 ppm dozlarında hazırlanarak kullanılmıştır. Bu hormonların 1000 ppm dozlarının hazırlanması için 20 $\mathrm{mg}$ hormon, 5000 ppm dozlarının hazırlanması için ise 100 mg hormon hassas terazi ile tartılmıştır. Sonrasında ise ayrı ayrı \%96'।ık etil alkolde çözündürülerek $20 \mathrm{gr}$ talk pudrası içine eklenmiş ve homojen olarak karıştırılarak hamur haline getirilmiştir. Homojen olarak hazırlanan bu hormonlar karanlık ve nemli olmayan bir ortamda 2-3 gün süreyle kurutulmuş ve daha sonra öğütülerek toz haline getirilmiştir. Hazırlanan hormonlar koyu renkli şişelerde ve buzdolabında muhafaza edilmiştir.

Çeliklerin köklendirme ortamlarına alındıktan sonra kallus ve kök gelişimleri takip edilerek ilk kallus ve ilk kök oluşum tarihleri tespit edilmiştir. Köklenme süreci tamamlandıktan sonra çeliklerde kök sayısı ve kök boyu ölçümleri yapılmıştır. Çeliklerde yapılan ölçümlere göre ilk kallus oluşumu, ilk kök oluşumu, kök boyu, kök sayısı ve köklenme yüzdesi verileri elde edilmiştir (Şekil 1). Bu verilere ilişkin ölçüm yöntemleri aşağıda verilmiştir:

- Kök Boyu (KB): Çeliklerin oluşturduğu köklerin uzunluğu cetvel ile ölçülerek, en uzun kök boyu olarak ifade edilmiştir.

- Kök Sayısı (KS): Çeliklerde oluşan toplam ana kök sayısı tespit edilmiştir.

Köklenme Yüzdesi (KY): Sökümden sonra kök oluşturan çeliklerin sayısı belirlenerek, toplam çeliğin yüzdesi olarak ifade edilmiştir.

Elde edilen veriler önce SPSS 22 (SPSS Inc) istatistik programı yardımıyla varyans analizine tabi tutulmuş olup, sera ortamları ve hormonlar açısından meydana gelen gruplar Duncan testi ile belirlenmiştir.
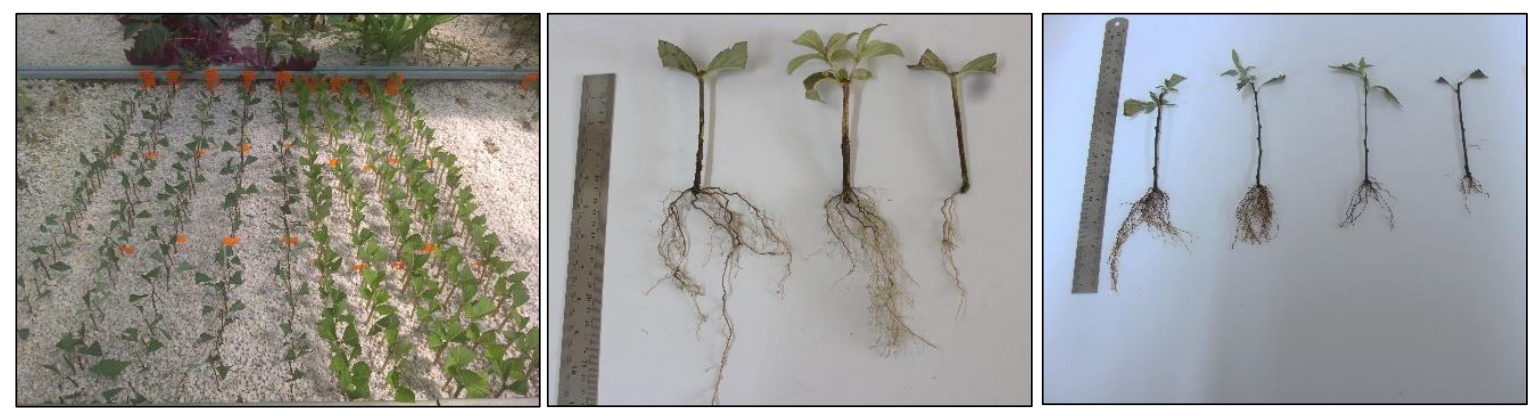

Şekil 1. Köklendirme ortamına aktarılan ve sökülen çeliklere ilişkin görseller

\section{BULGULAR}

\section{ilk Kallus ve Kök Oluşumuna iliş̧kin Bulgular}

Weigela floribunda türünde meydana gelen ilk kallus oluşumu çelikler köklendirme ortamına aktarıldıktan 41 gün sonra IBA 5000 ppm işleminde gözlemlenirken, ilk kök oluşumu ise yine aynı işlemde ve 44 gün sonunda meydana gelmiştir. Spiraea $x$ vanhouttei hibrit türü için kallus oluşumu tespit edilmemiş olsa da, türe ilişkin ilk kök oluşumunun 47 gün sonunda IBA 1000 ppm işleminde olduğu belirlenmiştir. Her iki türe ait çelikler köklendirme ortamlarından 104 gün sonra sökülmüştür (Şekil 2). 

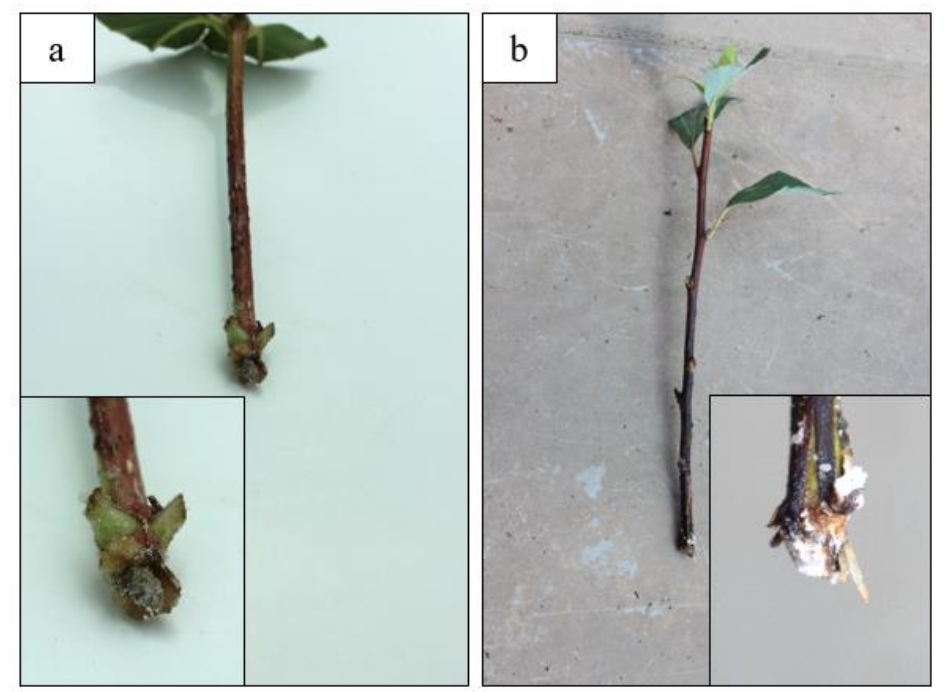

Şekil 2. Weigela floribunda'da ilk kallus oluşumu (a), Spiraea $x$ vanhouttei'de ilk kök oluşumu (b)

\section{Kök Boyu (KB) ve Kök Sayısına (KS) ilişkin Bulgular} Weigela floribunda türü ve Spiraea $x$ vanhouttei hibrit türü için araştırma sonucunda tüm sera ortamlarında ve tüm işlemlerde elde edilen kök boyu ve kök sayısı değerleri Çizelge 1 'de verilmiştir.

Weigela floribunda türünde elde edilen kök boyu değerlerine göre, Sera-1 ortamındaki Kontrol işleminde meydana gelen kök boyu $20.66 \mathrm{~cm}$ iken, IBA 1000 ppm işleminde en yüksek kök boyu değeri $26.46 \mathrm{~cm}$ olarak tespit edilmiştir. Sera-2 ortamında ise en yüksek kök boyu değeri $17.35 \mathrm{~cm}$ ile NAA 1000 ppm işleminde meydana gelmiştir. Bu sera ortamındaki Kontrol çeliklerinde oluşan kök boyu değeri ise $14.89 \mathrm{~cm}$ olarak belirlenmiştir. Aynı türe ilişkin kök sayısı değerleri irdelendiğinde, Sera-1 ortamındaki Kontrol işleminde kök sayısı 6.03 adet olurken, en yüksek kök sayısı değerinin 13.33 adet ile IBA 5000 ppm işleminde olduğu belirlenmiştir. Sera-2 ortamında ise Kontrol çeliklerinin kök sayısı 6.80 adet olurken, NAA 5000 ppm ile işlem gören çelikler en yüksek kök sayısı (12.13 adet) değerini oluşturmuştur. Spiraea $x$ vanhouttei hibrit türü için Sera-1 ve Sera-2 ortamlarındaki en yüksek kök boyları Kontrol çeliklerindeki sırasıyla 9.5 $\mathrm{cm}$ ve $12.46 \mathrm{~cm}$ olan değerler ile elde edilmiştir. Kök sayısı değerleri açısından Sera-1 ortamında 5.97 adet ile en yüksek kök sayısı IBA 5000 ppm işleminde meydana gelirken, Kontrol çeliklerinde de bu sonuca yakın bir değer (5.73 adet) elde edilmiştir. Sera-2 ortamındaki en yüksek kök sayısı değeri 7.23 adet ile IBA 5000 ppm işleminde tespit edilmiş olup, bu ortamdaki Kontrol işleminde elde edilen kök sayısı 4.03 adet olarak belirlenmiştir.

Çizelge 1 Kök boyu ve kök sayısına ilişkin elde edilen sonuçlar

\begin{tabular}{|c|c|c|c|c|c|}
\hline \multirow{2}{*}{ Sera Ortamları } & \multirow{2}{*}{ İşlemler } & \multicolumn{2}{|c|}{ Weigela floribunda } & \multicolumn{2}{|c|}{ Spiraea $x$ vanhouttei } \\
\hline & & $\mathrm{KB}(\mathrm{cm})$ & KS (adet) & $\mathrm{KB}(\mathrm{cm})$ & KS (adet) \\
\hline \multirow{6}{*}{ 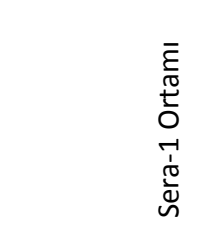 } & Kontrol & $20.66 \pm 9.19$ & $6.03 \pm 1.63$ & $9.5 \pm 2.16$ & $5.73 \pm 1.68$ \\
\hline & IBA 1000 & $26.46 \pm 8.63$ & $9.33 \pm 4.13$ & $7.97 \pm 4.72$ & $5.07 \pm 2.65$ \\
\hline & IBA 5000 & $23.65 \pm 8.38$ & $13.33 \pm 6.23$ & $8.68 \pm 3.45$ & $5.97 \pm 2.11$ \\
\hline & NAA 1000 & $20.74 \pm 9.01$ & $6.07 \pm 2.03$ & $7.83 \pm 4.55$ & $5.1 \pm 2.55$ \\
\hline & NAA 5000 & $24.74 \pm 9.70$ & $10.60 \pm 4.79$ & $7.81 \pm 4.11$ & $5.57 \pm 2.81$ \\
\hline & Ortalama & $23.25 \pm 9.16$ & $9.07 \pm 4.95$ & $8.36 \pm 3.91$ & $5.49 \pm 2.39$ \\
\hline \multirow{6}{*}{ 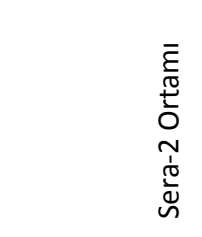 } & Kontrol & $14.89 \pm 6.02$ & $6.80 \pm 3.99$ & $12.46 \pm 6.78$ & $4.03 \pm 1.96$ \\
\hline & IBA 1000 & $13.40 \pm 6.94$ & $8.13 \pm 4.00$ & $6.38 \pm 4.24$ & $4.17 \pm 2.84$ \\
\hline & IBA 5000 & $13.59 \pm 8.03$ & $11.83 \pm 6.57$ & $8.20 \pm 4.73$ & $7.23 \pm 3.71$ \\
\hline & NAA 1000 & $17.35 \pm 5.51$ & $9.3 \pm 3.80$ & $9.13 \pm 5.41$ & $6.87 \pm 3.92$ \\
\hline & NAA 5000 & $14.17 \pm 5.48$ & $12.13 \pm 5.59$ & $5.46 \pm 5.70$ & $6.00 \pm 6.58$ \\
\hline & Ortalama & $14.68 \pm 6.56$ & $9.64 \pm 5.28$ & $8.33 \pm 5.90$ & $5.66 \pm 4.27$ \\
\hline
\end{tabular}

Sera ortamları bakımından kök boyu ve kök sayısı verilerinin değerlendirilmesi için $\mathrm{t}$ testi uygulanmıştır (Çizelge 2). Hem KB hem de KS açısından Spiraea $x$ vanhouttei için istatistiksel olarak anlamlı farklılıklar $(\mathrm{P}<0,05)$ ortaya çıkmazken, Weigela floribunda türünde
KB açısından seralar arasında istatistiksel olarak anlamlı farklılıklar $(P<0,05)$ meydana gelmiştir. Sera ortamlarında meydana gelen ortalama kök boyu ve kök sayısı değerleri de Çizelge 3'te verilmiştir. 
Çizelge 2 Sera ortamları açısından kök boyu ve kök sayısına ilişkin t testi sonuçları

\begin{tabular}{lllll}
\hline Ölçülen Değer & Tür & Serbestlik Derecesi & $\mathrm{F}$ & $\mathrm{P}$ \\
\hline \multirow{2}{*}{ KB } & Weigela floribunda & 298 & 12.215 & $0.000^{*}$ \\
& Spiraea $x$ vanhouttei & 298 & 25.935 & 0.956 \\
KS & Weigela floribunda & 298 & 1.222 & 0.333 \\
& Spiraea $x$ vanhouttei & 298 & 39.326 & 0.665 \\
\hline
\end{tabular}

*Önem düzeyi $(\mathrm{P})<0.05$

Çizelge 3 Sera ortamlarına göre ortalama kök boyu ve kök sayısı değerleri

\begin{tabular}{llll}
\hline Tür & Sera Ortamları & Ortalama KB (cm) & Ortalama KS (adet) \\
\hline \multirow{2}{*}{ Weigela floribunda } & Sera-1 Ortamı & 23.25 & 9.07 \\
& Sera-2 Ortamı & 14.68 & 9.64 \\
Spiraea $\times$ vanhouttei & Sera-1 Ortamı & 8.36 & 5.49 \\
& Sera-2 Ortamı & 8.33 & 5.66 \\
\hline
\end{tabular}

Weigela floribunda türü için Sera-1 ortamında $23.25 \mathrm{~cm}$ ortalama kök boyu ve 9.07 adet ortalama kök sayısı elde edilirken, Sera-2 ortamında ise $14.68 \mathrm{~cm}$ ortalama kök boyu ve 9.64 adet ortalama kök sayısı meydana gelmiştir. Spiraea $x$ vanhouttei hibrit türünde Sera-1 ortamında 8.36 $\mathrm{cm}$ ortalama kök boyu ve 5.49 adet ortalama kök sayısı meydana gelmiş olup, Sera-2 ortamında ise $8.33 \mathrm{~cm}$ ortalama kök boyu ve 5.66 adet ortalama kök sayısı tespit edilmiştir.

Çalışma kapsamında, hormonlara göre türlerin kök boyu ve kök sayısı bakımından farklılık gösterip göstermediğini belirlemek amacıyla varyans analizi yapılmıştır (Çizelge 4).

Çizelge 4 Hormonlar açısından kök boyu ve kök sayısına ilişkin varyans analizi sonuçları

\begin{tabular}{lllll}
\hline Ölçülen Değer & Tür & Serbestlik Derecesi & $\mathrm{F}$ & $\mathrm{P}$ \\
\hline \multirow{2}{*}{ KB } & Weigela floribunda & 299 & 0.816 & 0.516 \\
& Spiraea $x$ vanhouttei & 299 & 7.351 & $0.000 *$ \\
KS & Weigela floribunda & 299 & 18.76 & $0.000 *$ \\
& Spiraea $x$ vanhouttei & 299 & 3.451 & $0.009 *$ \\
\hline
\end{tabular}

*Önem düzeyi $(P)<0,01$

Kök boylarına ilişkin varyans analizi sonuçlarına göre, Weigela floribunda türü için $\mathrm{P}<0,01$ önem düzeyinde istatistiksel olarak anlamlı bir fark söz konusu olmazken, Spiraea $x$ vanhouttei hibrit türü için $\mathrm{P}<0,01$ önem düzeyinde istatistiksel olarak anlamlı farklılık bulunmaktadır. Kök sayılarına ilişkin varyans analizi sonuçları incelendiğinde ise her iki tür için de istatistiksel olarak anlamlı farklılıklar $(P<0,01)$ meydana gelmiştir.

Kök boyu ve kök sayısı değerleri üzerinde hormon uygulamaları ile meydana gelen grupları belirlemek amacıyla Duncan testi yapılmıştır (Çizelge 5).

Çizelge 5 Hormonlar açısından kök boyu ve kök sayısına ilişkin Duncan testi sonuçları

\begin{tabular}{|c|c|c|c|}
\hline Tür & İşlem & Ortalama KB (cm) & Ortalama KS (adet) \\
\hline \multirow{5}{*}{ Weigela floribunda } & Kontrol & 17.77 a & $6.42 c$ \\
\hline & IBA 1000 ppm & $20.62 a$ & $9.03 \mathrm{~b}$ \\
\hline & IBA 5000 ppm & $18.61 \mathrm{a}$ & $12.58 \mathrm{a}$ \\
\hline & NAA 1000 ppm & $19.06 \mathrm{a}$ & $7.68 \mathrm{bc}$ \\
\hline & NAA 5000 ppm & 19.46 a & $11.37 \mathrm{a}$ \\
\hline \multirow{5}{*}{ Spiraea $x$ vanhouttei } & Kontrol & $10.98 a$ & $4.88 \mathrm{bc}$ \\
\hline & IBA 1000 ppm & $7.17 \mathrm{~b}$ & $4.62 \mathrm{c}$ \\
\hline & IBA 5000 ppm & $8.44 b$ & $6.60 a$ \\
\hline & NAA 1000 ppm & $8.48 \mathrm{~b}$ & $5.98 \mathrm{ab}$ \\
\hline & NAA 5000 ppm & $6.64 b$ & $5.78 \mathrm{abc}$ \\
\hline
\end{tabular}

Duncan testi sonuçlarına göre, Weigela floribunda türü için ortalama kök boyu değerleri açısından tüm işlemlerde birbirine yakın sonuçlar elde edilmiş olup tek grup meydana gelmiştir. Yine de bu tür için en uzun ortalama kök boyu IBA 1000 ppm işleminde $20.62 \mathrm{~cm}$ olarak belirlenmiştir. Ortalama kök sayısı değerleri 
incelendiğinde, dört farklı grup meydana gelmiştir. Buna göre IBA 5000 ppm ve NAA 5000 ppm ile işlem görmüş çelikler, sırasıyla 12.58 adet ve 11.37 adet ortalama kök sayısı ile birinci grubu oluşturmuştur. 6.42 adet ortalama kök sayısı ile Kontrol işlemi ise son grubu oluşturmuştur. Spiraea $x$ vanhouttei hibrit türü için kök boyu açısından Duncan testi sonucunda iki farklı grup oluşmuştur. En yüksek ortalama kök boyu değerine sahip olan Kontrol işlemi $(10.98 \mathrm{~cm})$ birinci grubu meydana getirirken, birbirine yakın değerler alan diğer işlemler hep birlikte ikinci grubu oluşturmuştur. Kök sayısı bakımından ise beş farklı grup meydana gelmiştir. Buna göre IBA 5000 ppm ile işlem gören çelikler 6.60 adet ile en yüksek ortalama kök sayısına sahip olurken dördüncü grubu oluşturan Kontrol işleminde 4.88 adet kök sayısı meydana gelmiştir.

\section{Köklenme Yüzdesine (KY) iliş̧kin Bulgular}

Weigela floribunda türü ve Spiraea $x$ vanhouttei hibrit türüne ilişkin köklenen çelikler belirlendikten sonra köklenme yüzdeleri hesaplanmıştır. Çalışma sonucunda elde edilen köklenme yüzdesi değerleri Çizelge $6^{\prime} \mathrm{da}$ verilmiştir.

Çizelge 6. Köklenme yüzdesine ilişkin tüm işlemlerde elde edilen sonuçlar

\begin{tabular}{llll}
\hline \multirow{2}{*}{ Sera Ortamları } & İşlemler & KY $(\%)$ & \\
\cline { 2 - 3 } & Kontrol & 100.00 & Spiraea $x$ vanhouttei \\
\multirow{3}{*}{ Sera-1 Ortamı } & IBA 1000 & 96.67 & 100.00 \\
& IBA 5000 & 100.00 & 90.00 \\
& NAA 1000 & 100.00 & 100.00 \\
& NAA 5000 & 100.00 & 86.67 \\
& Kontrol & 96.67 & 90.00 \\
Sera-2 Ortamı & IBA 1000 & 93.33 & 90.00 \\
& IBA 5000 & 93.33 & 76.67 \\
& NAA 1000 & 100.00 & 86.67 \\
& NAA 5000 & 100.00 & 80.00 \\
\hline
\end{tabular}

Weigela floribunda türüne ait köklenme yüzdesi sonuçlarına göre, Sera-1 ortamında Kontrol, IBA 5000 ppm, NAA 1000 ppm ve NAA 5000 ppm işlemlerinde $\% 100$ ile en yüksek köklenme yüzdesi elde edilirken, IBA 1000 ppm işleminde de \%96.67'lik köklenme yüzdesi elde edilmiştir. Sera-2 ortamında ise \%100 ile en yüksek köklenme yüzdesi NAA hormonunun 1000 ve 5000 ppm dozlarında tespit edilmiştir. Bu ortamdaki Kontrol işleminde de \%96.67 ile yüksek bir köklenme başarısı oluşmuştur. Spiraea $x$ vanhouttei hibrit türü için Sera-1 ortamındaki en yüksek köklenme yüzdesi \%100 ile Kontrol ve IBA 5000 ppm işlemlerinde meydana gelmiştir. Sera-2 ortamında ise \%90 ile en yüksek köklenme başarısının Kontrol işleminde olduğu belirlenmiştir.
Sera ortamları bakımından köklenme yüzdesi değerleri için t testi uygulanmıştır (Çizelge 7). KY açısından hem Weigela floribunda için hem de Spiraea $x$ vanhouttei için istatistiksel olarak anlamlı farklılıklar $(P<0,05)$ meydana gelmiştir.

Sera ortamlarında meydana gelen ortalama köklenme yüzdesi değerleri Çizelge 8'de verilmiştir. Hem Weigela floribunda için hem de Spiraea $x$ vanhouttei için Sera-1 ortamında daha yüksek köklenme yüzdesi değerleri (sırasıyla, 99.33 ve 93.33) elde edilmiştir.

Çizelge 7 Sera ortamları açısından köklenme yüzdesine ilişkin t testi sonuçları

\begin{tabular}{lllll}
\hline Ölçülen Değer & Tür & Serbestlik Derecesi & $\mathrm{F}$ & $\mathrm{P}$ \\
\hline \multirow{2}{*}{$\mathrm{KY}$} & Weigela floribunda & 28 & 16.008 & $0.011^{*}$ \\
& Spiraea $x$ vanhouttei & 28 & 4.301 & $0.000^{*}$ \\
\hline
\end{tabular}

*Önem düzeyi $(\mathrm{P})<0.05$

Çizelge 8 Sera ortamlarına göre ortalama köklenme yüzdesi değerleri

\begin{tabular}{lll}
\hline Tür & Sera Ortamları & Ortalama KY (\%) \\
\hline \multirow{2}{*}{ Weigela floribunda } & Sera-1 Ortamı & 99.33 \\
& Sera-2 Ortamı & 96.67 \\
Spiraea $x$ vanhouttei & Sera-1 Ortamı & 93.33 \\
& Sera-2 Ortamı & 77.33 \\
\hline
\end{tabular}


Çalışma kapsamında, hormonlara göre türlerin köklenme yüzdesi açısından farklılık gösterip göstermediğini belirlemek için varyans analizi yapılmıştır (Çizelge 9). Köklenme yüzdelerine ilişkin varyans analizi sonuçlarına göre, Weigela floribunda ve Spiraea $x$ vanhouttei için
$\mathrm{P}<0,01$ önem düzeyinde istatistiksel olarak anlamlı farklılıklar meydana gelmiştir.

Köklenme yüzdesi değerleri üzerinde hormon uygulamaları ile meydana gelen grupları belirlemek amacıyla Duncan testi yapıımıştır (Çizelge 10).

Çizelge 9 Hormonlar açısından köklenme yüzdesine ilişkin varyans analizi sonuçları

\begin{tabular}{lllll}
\hline Ölçülen Değer & Tür & Serbestlik Derecesi & $\mathrm{F}$ & $\mathrm{P}$ \\
\hline \multirow{2}{*}{$\mathrm{KY}$} & Weigela floribunda & 29 & 5.364 & $0.003^{*}$ \\
& Spiraea $x$ vanhouttei & 29 & 4.667 & $0.006 *$ \\
\hline
\end{tabular}

*Önem düzeyi $(\mathrm{P})<0.01$

Çizelge 10 Hormonlar açısından köklenme yüzdesine ilişkin Duncan testi sonuçları

\begin{tabular}{lll}
\hline Tür & İşlem & Ortalama KY (\%) \\
\hline & Kontrol & $98.34 \mathbf{b}$ \\
Weigela floribunda & IBA $1000 \mathrm{ppm}$ & $95.00 \mathbf{c}$ \\
& IBA $5000 \mathrm{ppm}$ & $96.67 \mathbf{~ b c}$ \\
& NAA $1000 \mathrm{ppm}$ & $100.00 \mathbf{a}$ \\
& NAA $5000 \mathrm{ppm}$ & $100.00 \mathbf{a}$ \\
& Kontrol & $95.00 \mathbf{a}$ \\
Spiraea $x$ vanhouttei & IBA $1000 \mathrm{ppm}$ & $83.34 \mathbf{a b}$ \\
& IBA $5000 \mathrm{ppm}$ & $93.34 \mathbf{a}$ \\
& NAA $1000 \mathrm{ppm}$ & $83.34 \mathbf{a b}$ \\
& NAA $5000 \mathrm{ppm}$ & $71.67 \mathbf{b}$ \\
\hline
\end{tabular}

Duncan testi sonuçlarına göre, Weigela floribunda için ortalama köklenme yüzdesi değerleri açısından dört grup meydana gelmiştir. Bu tür için en yüksek köklenme yüzdesinin (\%100) elde edildiği NAA 1000 ppm ve NAA 5000 ppm işlemleri birinci grubu oluştururken, \%98.34 köklenme yüzdesi sonucuyla Kontrol işlemi ikinci grubu meydana getirmiştir. Spiraea $x$ vanhouttei için köklenme yüzdesi açısından Duncan testi sonucunda üç farklı grup oluşmuştur. En yüksek ortalama köklenme yüzdesi değerlerine sahip olan Kontrol (\%95) ve IBA 5000 ppm (\%93.34) işlemleri birinci grubu oluşturmuştur.

\section{TARTIŞMA VE SONUÇ}

Çelikle üretme üzerine sera ortamı ve büyüme hormonlarının etkilerinin araştırıldığı bu çalışmada, Weigela floribunda (Sieb. and Zucc.) K. Koch türünün yumuşak çeliklerinde Sera-1 ortamında yer alan Kontrol, IBA 5000 ppm, NAA 1000 ppm ve NAA 5000 ppm işlemlerinde ve ayrıca Sera-2 ortamındaki NAA 1000 ppm ve NAA 5000 ppm işlemlerinde \%100'lük köklenme başarısı elde edilmiştir. Vlad vd. (2010), Weigela florida türünün çelikle üretilmesi üzerine köklendirme ortamı etkisini incelemiştir. En yüksek köklenme yüzdesini $\% 50$ turba $+\% 50$ perlit karışım ortamında $\% 84$ ile elde etmişlerdir. Dolayısıyla, bu çalışma ile kıyaslandığında çalışmamızda daha yüksek köklenme başarısı elde edilmiştir. Kök boyu açısından mevcut çalışmada araştırılan tüm işlemler arasından en iyi sonuç Sera-1 ortamındaki IBA 1000 ppm işleminde $(26.46 \mathrm{~cm})$, kök sayısı açısından ise aynı sera ortamındaki IBA 5000 ppm işleminde (13.33 adet) elde edilmiştir. Weigela floribunda türü için hava ve köklendirme ortamının birbirine yakın sıcaklıklarda olması ve IBA hormonunun kullanımı ile zaten köklenmesinde sorun olmayan tür için morfolojik özellikler açısından daha kaliteli fidanlar yetiştirilebilir.

Spiraea $x$ vanhouttei (Briot) Zabel hibrit türünde \%100 oranında elde edilen köklenme başarısı Sera-1 ortamında yer alan Kontrol ve IBA 5000 ppm işlemlerinde elde edilmiş olsa da, kök boyu (12.46 cm ile Kontrol işleminde) ve kök sayısı (7.23 adet ile IBA 5000 ppm işleminde) açısından en iyi sonuçların Sera-2 ortamında meydana geldiği belirlenmiştir. Ion (2011) Spiraea salicifolia türüne ilişkin yaptığı çalışmada, en yüksek köklenme başarısını yumuşak çeliklerde $\% 61$, sert çeliklerde $\% 93$ olarak elde etmiştir. Yapılan çalışmaya kıyasla, Spiraea $x$ vanhouttei hibrit türünün yumuşak çelikler ile üretilmesinde hava ve 
köklendirme ortamının yaklaşık $20 \pm 2^{\circ} \mathrm{C}$ olması, perlit köklendirme ortamının kullanılması ve daha düşük bütçeler ile üretimin yapılabilmesi adına hormonsuz üretim yapılarak çok yüksek köklenme başarısı elde edilebilmektedir. Ancak yine de IBA hormonunun kullanımı, fidanların ilerideki yaşam kabiliyetini önemli oranda etkileyen kök sayısı faktörünü olumlu yönde etkilediği için önerilebilir.

\section{KAYNAKLAR}

Ay S (2009) Süs bitkileri ihracatı, sorunları ve çözüm önerileri: Yalova ölçeğinde bir araştırma. Süleyman Demirel Üniversitesi, İktisadi ve İdari Bilimler Fakültesi Dergisi 14, 3: 423-443

Boydak M, Çalışkan S (2014) Ağaçlandırma. OGEM-VAK yayınları, CTA Tanıtım Rek. Hiz. Org. Basın Yayın Bil. San. Tic. Ltd. Şti. Ankara.

Çetin V (2002) Meyve ve sebzelerde kullanılan bitki gelişmeyi düzenleyiciler. Gıda ve Yem Bilimi-Teknolojis 2.

Demirbaş A R (2010) Süs bitkileri yetiştiriciliği. Samsun Valiliği, il Tarım Müdürlüğü, Çiftçi Eğitimi ve Yayım Şubesi Yayını, Samsun

Epstein E, Ludwig-Müller J (1993) Indole-3-butyric acid in plants: occurrence, synthesis, metabolism, and transport. Physiol. Plant, 88: 382-389

Ermeydan M, Ermeydan N, Bekaroğlu G (2011) Bitki Bilgisi. Bahçıvanlık El Kitabı, İstanbul Büyükşehir Belediyesi Yayınları, İstanbul, s.13107.

Grunewald W, Noorden GV, Isterdael GV, Beeckman T, Gheysen G, Mathesius U (2009) Manipulation of auxin transport in plant roots during Rhizobium Symbiosis and Nematode Parasitism. The Plant Cell, 21(9): 2553-2562

Ion S (2011) Propagation of some ornamental species (Ligustrum ovalifolium Hassk., Spiraea salicifolia L., Forsythia sp.) at the Botanical Garden" Al. Buia" from Craiova. Annals of the University of Craiova-Agriculture, Montanology, Cadastre Series, 41(2): 237242

Jaenicke H, Beniest J (2002) Vegetative tree propagation in agroforestry. International Centre for Reseach in Agroforestry (ICRAF), Nairobi, Kenya

Kaynak, L., Ersoy, N., 1997. Bitki büyüme düzenleyicilerinin genel özellikleri ve kullanım alanları. Akd. Üniv. Zir. Fak. Dergisi, 10: 223236.

Kızıloğlu R, Uzunöz M, Topal i (2012) Yalova ilinde kesme çiçek yetiştiriciliğinin üretim maliyeti ve karlılığı. Atatürk Üniversitesi Ziraat Fakültesi Dergisi 43, 1: 65-68

Megep (2007) Bahçecilik, Çelikle üretim. Mesleki Eğitim ve Öğretim Sisteminin Güçlendirilmesi Projesi, 46, Ankara

Şirin U (2003) Peyzaj planlama çalışmalarında kullanılabilecek bazı çalı ve ağaççı formundaki bitkilerin farklı üretim teknikleri ile çoğaltılabilirliklerinin ve fidan performanslarının belirlenmesi. Adnan Menderes Üniversitesi Fen Bilimleri Enstitüsü Doktora Tezi, Aydın

Ürgenç S (1992) Ağaç ve süs bitkileri fidanlık ve yetiştirme tekniği. İstanbul Üniversitesi Orman Fakültesi, İstanbul

Vlad M, Vlad I, Vlad I, Bartha S, Vlad R (2010) The Substratum Influence on cutting's rooting of Weigela florida. Analele Universității din Oradea, Fascicula: Protecția Mediului 15: 339-341

Weaver R.J (1972). Plant Growth Substances in Agriculture. W.H. Freeman and Company. San Frasisco, 504s.

Zenginbal H, Özcan M, Haznedar A (2006). Kivi (Actinidia deliciosa, A. Chev.) odun çeliklerinin köklenmesi üzerine IBA uygulamalarının etkisi. OMÜ Zir. Fak. Dergisi, 21(1):40-43 